\title{
A new scale of brand lovemarks
}

\author{
Avichai Shuv-Ami
}

\begin{abstract}
Purpose of the paper: The current study attempts to provide a new lovemarks scale that predicts consumers' behavioral outcomes. This scale also bridges over some of the inconsistencies of the measurement of "brand love" that also measure "brand respect".

Methodology: In order to test the Lovemarks scale, 3 studies were conducted. Study 1 applied Exploratory Factor Analysis using Principal Component exploratory factor analysis. Study 2 used second-order confirmatory factor analysis (CFA) with a maximum likelihood fitting function of the two-component solution. Study 3 measured the nomological validity of the assessed Lovemarks scale by testing its relations with four other relevant scales.

Results: Using EFA and CFA, the reliability and validity of the scale were divided into four different product categories: dairy companies, cellular network providers, banks, and fashion retail chains. The scale does have strong positive correlations with attitude, preference, price premium and recommendation.

Research limitations: The main limitation of the current research is that Study 2 used CFA testing only for second-order factors and not third-order factors, which would have also enabled the testing of the antecedents of the scale's items (such as intimacy or trust).

Practical implications: This scale helps to predict consumer behavior and set an effective marketing strategy for the brand. It thus gives directions for product adjustments and establishes effective advertising, marketing communication strategies and brand pricing strategy.

Originality of the paper: The current study is testing a new Lovemarks scale on the basis of four different product categories: dairy companies, cellular network providers, banks, and fashion retail chains.
\end{abstract}

Key words: lovemarks; brand; love; respect; recommendation; price premium

\section{Introduction}

The current study has tested a new scale of "Lovemarks" that may predict consumers' behavioral outcomes. The Lovemarks theory, introduced by Kevin Roberts (2004), CEO of Saatchi and Saatchi, suggests that two components for "Lovemarks brands", "love" and "respect", are the main drivers of brand loyalty. The importance of this theory and the construction of a short and simple scale is based on the idea that "Lovemarks" may explain why consumers feel loyalty and attachment to one brand and not to another. As Roberts described it, the loyalty for "Lovemarks" brand is "loyalty beyond reason" (2005, p. 66) when citing a loyal Apple user - "After 14 years I am still in love. To be honest I don't know why I feel that way..." (Roberts, 2005, p. 200). 
sinergie Vol. 35, N. 102, 2017

A recent study by Batra et al. (2012) has distinguished between "love emotion" and "love relationship". This study suggests that brand love as a "love emotion" is temporary and episodic while a "love relationship" can last for years. However, the Lovemarks theory (Roberts, 2004) argues that "love emotion" combined with "respect" can determine the consumer's relationship with a brand. Kevin Roberts (2004) suggests that both components for "Lovemarks brands"can affect satisfaction and loyalty. To date, no research offers an explicit scale which effectively measures a brand's Lovemarks.

Despite its importance, Roberts $(2004,2005)$ did not offer a published measurement scale to measure brand Lovemarks and research on the Lovemarks theory has been light and limited so far (Cho et al. 2015; Pavel, 2013, Pawle and Cooper 2006; Shuv-Ami, 2011; Shuv-Ami, 2013). However, related marketing literature on "brand love" attracted much attention in recent years (e. g. Batra et al., 2012; Broadbent, et al., 2010; Maxian et al., 2013; Ortiz and Mary, 2011; Patwardhan and Balasubramanian, 2013; Cho et al. 2015; Rossiter, 2012; Rossiter and Bellman, 2012; Sarkar, 2011). This stream of research has mainly focused on the conceptualization of "brand love" but has used different types and inconsistent measurement in relation to "brand love". Furthermore, the marketing literature has neglected the other decisive component of brand Lovemarks, i.e., "brand respect".

For example, Batra, Ahuvia, and Bagozzi (2012) published a new measurement of "brand love" in the Journal of Marketing that was harshly criticized by Rossiter (2012) in a study published in Marketing Letters. The purpose of the current study is to provide a scale that will bridge over most of the inconsistences of the measurement of "brand love" and will offer a new scale of Lovemarks that also measures "brand respect". This documented research will test this new Lovemarks scale on four different product categories: dairy companies, cellular network providers, banks, and fashion retail chains.

\section{Theoretical conceptualization}

The Lovemarks theory suggests (Figure 1) that brands with low love and low respect are merely available "products". Brands with high love and low respect are "fads" that will eventually disappear. Brands with low love and high respect are "real brands". Brands with both high love and high respect are "Lovemarks", brands with "loyalty beyond reason". Respect, according to Roberts, represents the more functional attributes of the brand. Such attributes determine consumer perceptions of a product/ brand and the way consumers assess a brand's functional performance, especially quality and reliability. The sums of these characteristics reflect consumer preference for the brand (Roberts, 2005, pp. 60-63). Love, on the other hand, represents the brand's associated emotional attributes of "mystery", "sensuality" and "intimacy", which denote the relationship of the user to the brand (Roberts, 2005, pp. 78-79). Such intimacy raises passion in the user and ensures the user's deeply felt loyalty and commitment to the brand. Mystery is driven by great stories, myths and icons; "sensuality" 
is driven by our senses (sound, sight, smell, touch and taste); and "intimacy" is impelled by the relationship the user has with the brand. Such relationship includes empathy and commitment, as well as the passion the brand arouses in users. Pawle and Cooper's (2006) findings support the concept of the Lovemarks theory that intimacy, mystery, and sensuality - as well as trust, reputation, and performance - decisively influence the consumers' love and respect for specific brands. Those feelings that most strongly shape consumer choice are the emotional factors which lead to brand "love".

Fig. 1: Lovemarks brand classification

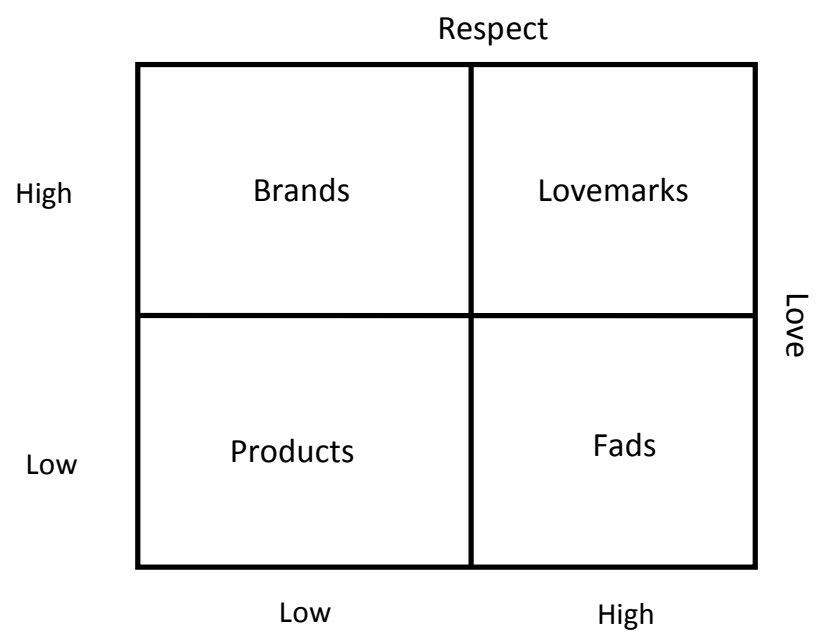

Pawle and Cooper, 2006, p. 39

However, Cho et al. (2015), in testing the dimensions of "Brand Lovemarks" as suggested by Roberts (2004), found that, contrary to Roberts' theory, mystery and sensuality are more related to respect than love. The current study offers a new and different scale of Lovemarks. Similar to Roberts' theory, the present scale measures both respect for a brand's functional performance and love that represents its emotional associations with the brand. However, instead of using intimacy, mystery and sensuality to represent love, the current study is using intimacy, longing and joy, which are well established in the marketing literature (e.g., Ahuvia, 2005, Albert et al. 2008, Carroll and Ahuvia, 2006; Sarkar, 2011; Sternberg, 1986; Whang et al., 2004). The notion that consumers are influenced by both the brand's functional attributes and the brand's emotional associations is well-established in brand equity literature (Aaker, 1996; Keller, 1993, 2008; Keller and Lehmann, 2006). While the influence of perceived quality performance on consumer decision-making has been extensively examined (e.g., Helson, 1964; Howard and Sheth, 1969; Mano and Oliver, 1993; Oliver, 1980; Tsiotsou, 2006; Weaver and Brickman, 1974), little research has been conducted on the way love can affect the process of consumer choice and brand selection (e.g., Ahuvia, 2005; Batra et al. 2012; Carroll and Ahuvia, 2006; Bergkvist and Bech-Larsen, 2010; Sarkar, 2011). 


\section{sinergie}

Vol. 35, N. 102, 2017

Love

The current study proposes that love has three dimensions; intimacy, longing and joy. Love of a brand, in the marketing literature, is mainly considered as a romantic sort of love (e.g., Ahuvia, 2005; Carroll and Ahuvia, 2006; Sarkar, 2011; Whang et al., 2004) animated by intimacy and passion (Sternberg, 1986). Caroll and Ahuvia define love for a brand as "the degree of passionate emotional attachment that a person has for a particular trade name" (2006, p. 5). Sternberg's research (1986) offered a tricomponent model of love that includes intimacy, passion and commitment. Shimp and Madden's (1988) tri-component model of love consisted of liking, yearning and commitment. According to Sarkar both Sternberg's research (1986) and Shimp and Madden's tri-component models "perfectly correspond" since romantic brand love is "a combination of emotion (or intimacy or liking) and passion (or yearning) for a brand" (2011, p. 83). However, a commitment that represents a series of attachments (Keller and Lehmann, 2006; Shuv-Ami, 2012) is probably a result of love and not love itself. The drivers of love in the Lovemarks theory are mystery, sensuality and intimacy (Roberts 2005). Intimacy, or liking, may be derived from a romantic emotion towards the loved brand. Passionate longing, or yearning for a loved brand, may be a result of brand mystery and sensuality. Whang, et al. (2004) used Rubin's scale (1970) for studying bikers' love for their motorcycles. Such a scale directly measured the romantic emotion of intimacy and passionate longing. While intimacy was measured by the statement: "I am in love with my bike", passionate longing was measured by the statement "If I could never be on my bike, I would feel miserable". Similarly, Bergkvist and Bech-Larsen (2010) measured brand love with two items, one measuring expressed love relating to the intimacy of romantic love and the other measuring longing as a passionate or romantic sense of loss in case of unavailability.

Batra et al. (2012) suggested a new and complex measurement of "brand love" that includes enduring passion, self-brand integration, longterm relationship, positive emotional connection, anticipated separation distress, overall attitude valence and attitude Strength. This measurement was criticized by Rossiter (2012) on two grounds: first, he argued that "Brand love is a discrete, categorical, emotional state which cannot be validly measured on a continuous answer scale" (p. 7). However, he didn't offer a completely new measure of "brand love", but merely suggested a that "brand love" should not be represented just with its positive aspect (ranging from liking to loving) but also with the negative emotions' of "brand hate" (a 5-level scale of "hate - dislike - neutral - like - love"). $\mathrm{He}$ therefore offers a new type of scale - a continuous and single item of "Brand Love-Hate" scale and not a "Brand Love" scale. The second criticism was that the new scale of brand love of Batra et al. (2012) did not measure only love but also "off-attributes" (e.g., "involvement", "commitment", "very attached", "satisfaction", and "compares well with ideal product") and "additive" components (e.g. "positive-negative", "favorable-unfavorable", "meets needs perfectly" and "makes life worth living"). Moreover, Rossiter argued that "Brand love is achieved only when 'Deep Affection' (not "Positive Affect", which is too weak an attribute) and 'Separation Anxiety' 
(not 'Anticipated' anxiety, which is an oxymoron) are jointly felt in relation to the potential love object" (p. 908). While it seems that Batra et al. (2012) used many "off-attributes" and "additive" components", they also measured the deep affection of passionate desire leading to a likely separation anxiety. Despite this disagreement and while answering to Rossiter's critique, Ahuvia, Bagozzi and Batra (Ahuvia et al. 2014) agree with Rossiter on the "importance of brand love" (p. 242) in predicting behavioral outcomes.

Some of the items used by Batra et al. (2012) to measure brand love are shared with earlier marketing literature including; passionate "feeling of desire", "feeling of longing" and the "pleasurable" feeling toward brand (p. 8). However, the focus of Batra et al. (2012) was not on the passion and joy of brand love but on the related consequences of brand love. Carroll and Ahuvia (2006) measured the joy or pleasure of love with "This brand makes me feel good", "This brand makes me very happy" or "This brand is a pure delight" (p. 84). Sarkar (2011) argued that as a part of love a "romantic person can imagine several things beyond reality and by doing this he/ she creates pleasurable experiences surrounding any consumption act" (p. 86). Albert et al. (2008) found empirically that French participants who fully agree that they are in love with their brand tend to use words such as "pleasure" and "dream" to describe their love. These researchers concluded that the two dimensions that are explicitly shared by French and Americans are the pleasure and passionate love that are associated with a brand.

\section{Respect}

The dimensions of respect, according to Roberts (2005) are functional and represent brand quality and reliability or trust. The current research also suggests that honor toward the brand directly reflects Roberts' notion of consumer respect for that brand.

The concept of brand respect has not been widely discussed in the marketing literature. Pawle and Cooper's testing (2006) for Lovemarks theory found that brand trust, reputation, and performance are the main influences on brand respect. While marketing research does not explicitly measure the concept of respect, it does test the nuanced way respect figures in the process of brand selection.

Research into the functional attributes of products and brands has generally indicated that quality performance drives brand relationship and thus has a positive effect on satisfaction, loyalty or commitment and purchase intentions. Oliver (1980), for example, found that consumer satisfaction is a function of expecting a product's quality and that such satisfaction influences post-purchase attitudes and purchase intentions. Conversely, any discrepancy between expectations and perceived quality performance results directly in brand dissatisfaction. Churchill and Suprenant (1982) argued that in relation to durable goods, a direct quality performancesatisfaction link accounts for most of the variance in satisfaction. Mano and Oliver (1993) showed that product quality evaluation (utilitarian and hedonic judgment) has a direct influence on pleasurable effect and a distinct product satisfaction. Bou-Llusar et al. (2001) found that overall customer satisfaction acts as a mediating variable on the relationships between a firm, perceived quality and customer purchase. Tsiotsou (2006) noted that 
sinergie

italian journal of management Vol. 35, N. 102, 2017

perceived quality had both a direct and an indirect effect (through overall satisfaction) on purchase intentions; overall satisfaction had a direct effect on purchase intentions; and involvement had an indirect effect on purchase intentions through overall satisfaction and perceived quality. Xie et al. (2015) found that trust is affected by brand quality and affects behavioral intentions. Chaudhuri and Holbrook (2001) examined both the functional and emotional aspects of the brand and showed that brand trust and brand effects (emotions toward the brand) influenced purchase loyalty (purchase intention) and attitudinal loyalty, which was measured as commitment.

\section{The model}

The model suggested here proposes that Lovemarks represent the driver of brand relationship. Thus, the combination of the emotional and romantic love toward the brand with respect to its functional performance will drive the relationship with the brand. Based on the above, the current study attempts to define "brand love", "brand respect" and brand "Lovemarks".

While the current study supports the notion that romantic love is driven by intimacy and passion, it suggests that the passionate component of love has one aspect of "joy" and one of "longing". This study seeks to expand Caroll and Ahuvia's (2006) definition of romantic love and define it as the degree of emotional intimacy and passionate joy and possible longing (in case of unavailability) that a person has for a particular trade name.

Respect is the functional dimension of Lovemarks that represents the perception of brand quality, brand reliability or trust and the overall honor a person has for a particular trade name. Lovemarks are a market position in the mind of consumers that represents both high love and high respect for a particular trade name.

Fig. 2: The suggested Brand Lovemarks Model
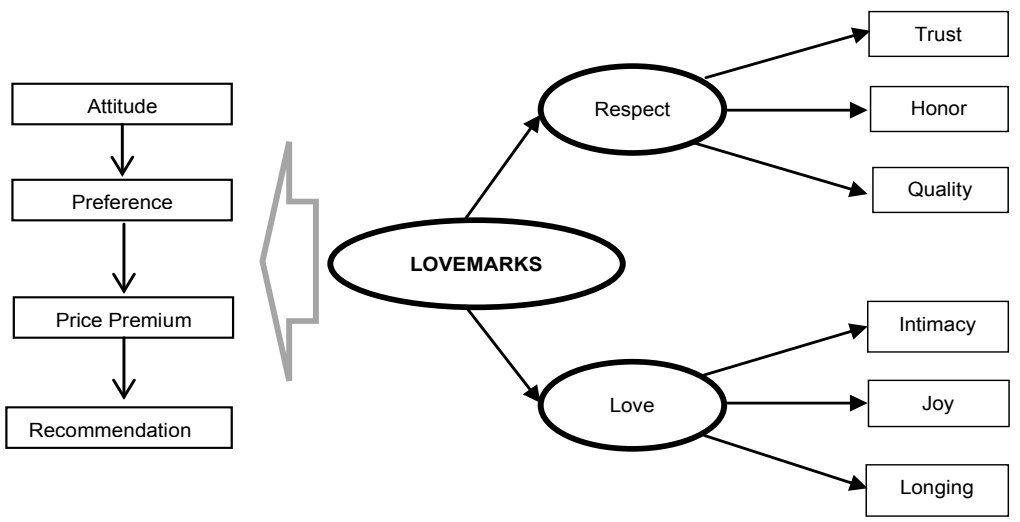

Source: Autor's elaboration

The three dimensions suggested here for love are "Intimacy" of love, "Joy" of love and passionate "Longing" for the brand. The three dimensions for respect are "Trust" in the brand performance, "Honor" for the brand's performance and the "Quality" of the brand performance. These two build 
brand Lovemarks which affect consumers' relationship with the brand. Such a relationship represents the consumer's attitude toward the brand, their brand preference, their willingness to pay price premiums and recommend the brand to others. Figure 2 represents the model underlying the suggested Lovemarks scale. The combined effect of "love" and "respect" is reflected in the overall Lovemarks scale. Thus, it is a reflective model that affects the overall Lovemarks and whose dimensions are expected to reflect a high correlation (Jarvis et al., 2003).

\section{Hypotheses}

Based on the above arguments, hypotheses regarding both the measurement and structural parts of the Lovemarks brand's nomological net were the following:

H1: Two oblique first-order factors - love and respect - suffice to account for the covariations of Lovemarks brand scale items.

$\mathrm{H} 2$ : The second-order factors that represent the overall brand Lovemarks underlie the first-order factors.

The first two hypotheses, described in Figure 3, show the total structural model hypothesized here.

The last hypothesis attempts to establish the nomological validity of the Lovemarks scale suggested in the current study. This scale's validity is tested against four variables that represent important aspects of brand relationship (Figure 3): overall attitude, preferred brand, purchase intention and recommendation intention.

H3: The total score of Lovemarks scale will positively correlate with overall attitude toward the brand, recommendation intention, brand preference and the willingness to pay price premiums for the brand.

\section{Methodology}

In order to test the Lovemarks scale 3 studies were conducted. The data for all of the studies were collected from an Internet panel.

Study 1 applied Exploratory Factor Analysis using Principal Component exploratory factor analysis with varimax rotation in order to extract a twofactor solution. This analysis examined the dimensionality of Lovemarks, as measured by the 6-item Lovemarks scale.

Study 2 used a second-order confirmatory factor analysis (CFA) with a maximum likelihood fitting function will be used to specify and confirm the two-component solution obtained from the exploratory factor analysis and to take the hierarchical structure of Lovemarks (see Figure 2) into account. This approach will provide a more rigorous check of the appropriateness of the Lovemarks scale items than its exploratory counterpart to measure their corresponding latent love and respect constructs.

Study 3 measured the nomological validity of the assessed Lovemarks scale by testing its relations with four relevant scales - overall brand attitude, brand recommendation, intentions, and brand preference - in its hypothesized nomological network. The correlations were estimated by fitting the measurement model for the Lovemarks scale with all possible 
correlations between it and the other four variables and among the variables themselves.

Fig. 3: The hypothesized measurement model of the Brand Lovemarks Scale

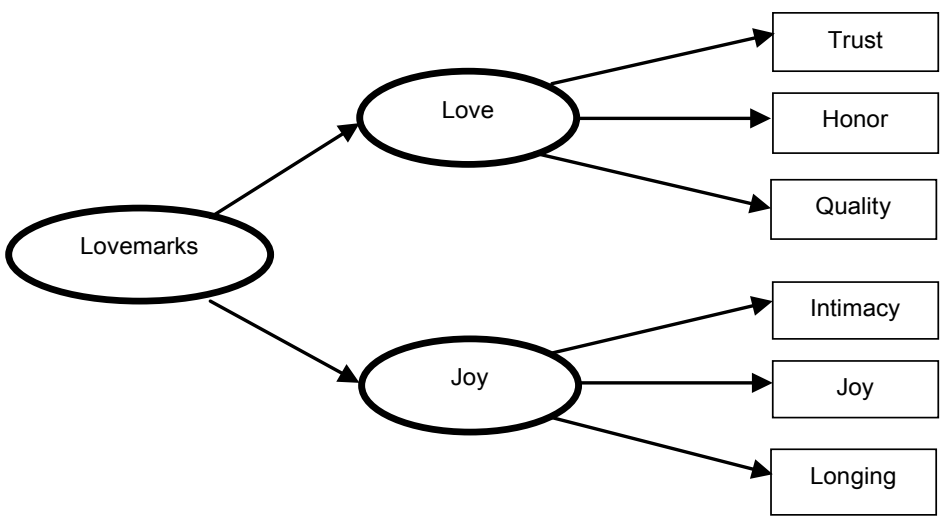

Note. Ovals represents a latent factor; rectangles represent an observed item (see below); one direction arrows represent a loading (direct effect of a factor on its indicator).

Source: Autor's elaboration

The reliability of all factors for the Lovemarks scale and for all other scales were tested for internal consistency using Cronbach's alpha, and expected to be above .70 (Nunnally, 1978).

The study tested the Lovemarks scale in relation to four different product categories that constitute a major part of household consumption: dairy companies, cellular network providers, banks, and fashion retail chains.

\section{Measurements}

The two constructs that constitute the Lovemarks scale are love and respect. The current study conceptually follows the notion of brand romantic love as suggested by several studies (Bergkvist and Bech-Larsen, 2010; Carroll and Ahuvia, 2006; Pawle and Cooper, 2006; Sarkar, 2011) to measure love. The current research used three items to measure love. Two of the items were adopted from from Bergkvist and Bech-Larsen (2010) and the third item (item 2) was adopted from Carroll and Ahuvia (2006) and represented the pleasure of love or the "joy of love" in using the brand. Item 1 was a direct measure of love that represented "intimacy" love (Bergkvist and Bech-Larsen, 2010) and 3 represents "longing" and a sense of loss of a loved brand. The questions used a 10-point scale asking respondents to agree or disagree with the statements:

Item 1: I love my main brand.

Item 2: I very much enjoy using the products/services of my main brand. Item 3: I would very much miss my main brand if it were no longer available. 
Respect was measured through three questions. Following the Lovemarks theory (Roberts 2005), three aspects of respect were measured: the first item dealt with the trust the customer feels towards the brand, the second item dealt with honor of the brand and third item dealt with brand quality. The questions used a 10-point scale asking respondents to agree or disagree with the following statements:

Item 4: My main brand is a brand you can trust.

Item 5: My main brand is an honored brand.

Item 6: My main brand is a quality brand.

Overall positive attitude was measured accordingly: "Please rate from 1 to 10 the way you overall feel and think about the brand you most often use, one indicating 'a very poor brand' and 10 'a very good brand". Brand preference was measured by means of a direct question: "If you had no limitations, please rate how likely are you to prefer your main brand from 1 to 10 ?" where 1 indicates 'Definitely would not prefer" and 10 means 'Definitely would prefer". The willingness to pay price premiums for the brand was measured by the following question "please from 1 to 10 how much do you agree or disagree with the statement: 'I am willing to pay more to continue to buy my main brand', where 1 means you 'completely disagree' with the statement and 10 that you 'completely agree' with the statement". Brand recommendation intention was measured using a modified Markey and Reichheld (2008) advocate measure (Net Promoter Scores - NPS): "Please rate from 1 to 10 how likely you are to recommend the brand you most often use, where 1 indicates 'Definitely would not recommend' and 10 means 'Definitely would recommend"

\section{Study 1: Exploratory factor analysis}

\section{Participants}

This study consists of 4 samples corresponding to the four groups of products: banks, dairy products, fashion retail chain, and cellular providers. In the banks sample 185 customers participated, 52\% of which were female, mean age $41.1(S D=15.1) .168$ customers participated in the dairy products sample, $51 \%$ of which were female, mean age $42.2(S D=14.7) .174$ customers participated in the fashion sample, $47 \%$ of which were female, mean age $41.3(S D=14.9) .181$ customers participated in the cellular products sample, $49 \%$ of which were female, mean age $42.6(S D=15.7)$. All participants were asked to answer the Lovemarks questionnaire with regard to the products of interest. The data for this study was collected from an Internet panel.

\section{Results}

For each sample, the 6 items of the Lovemarks Scale were subjected to exploratory factor analysis (EFA) with varimax rotation. Thus, four EFAs were conducted. According the criterions of eigenvalue $>1$ and Screen test (Hair et al., 2006) two factors were extracted. The two factors solution of each sample is presented in table 1 . On the basis of hypothesized structure and items content, I labeled the two factors "respect" and "love". These factors accounted for a range from $89.1 \%$ to $92.2 \%$ of common variance in 
sinergie Vol. 35, N. 102, 2017

the four samples, above the recommended minimum threshold of $60 \%$. In all samples, all items loaded highest on the appropriate factor and had substantive loadings that exceeded 6 .

Cronbach's alpha coefficients for the three-item respect scale were high for the four groups of products: for banks $\alpha=.98$, for dairy products $\alpha=.94$, for fashion $\alpha=.96$, and for cellular providers $\alpha=.96$. Similarly, Cronbach's alpha coefficients for the three-item love scale were high: for banks $\alpha=.91$, for dairy products $\alpha=.92$, for fashion $\alpha=.93$, and for cellular providers $\alpha$ $=.94$. Reliabilities of the total 6 items were also high for all four groups of products; for banks $\alpha=.96$, for dairy products $\alpha=.95$, for fashion $\alpha=.96$, and for cellular providers $=.96$. Correlations among the factors were $r=$ $.74, p<.001$ for banks, $r=.80, p<.001$ for dairy products, $r=.80, p<.001$ for fashion, and $r=.82, p<.001$ for cellular.

Tab. 1: Factor analysis of the Brand Lovemarks Scale

\begin{tabular}{|c|c|c|c|c|c|c|c|c|}
\hline & \multicolumn{2}{|c|}{ Banks } & \multicolumn{2}{|c|}{ Dairy } & \multicolumn{2}{|c|}{ Fashion } & \multicolumn{2}{|c|}{ Cellular } \\
\hline & Respect & Love & Respect & Love & Respect & Love & Respect & Love \\
\hline Trust & .92 & .36 & .86 & .41 & .88 & .45 & .91 & .36 \\
\hline Honor & .91 & .42 & .86 & .41 & .88 & .40 & .89 & .41 \\
\hline Quality & .89 & & .79 & .49 & .84 & .43 & .74 & .56 \\
\hline Intimacy & .47 & .80 & & .88 & .35 & .86 & & .90 \\
\hline Joy & & .91 & .45 & .82 & .53 & .80 & .54 & .76 \\
\hline Longing & .57 & .64 & .48 & .82 & .52 & .77 & .46 & .84 \\
\hline Rotated eigenvalue & 3.22 & 2.31 & 2.75 & 2.60 & 2.83 & 2.65 & 2.80 & 2.70 \\
\hline$\%$ of explained variance ${ }^{a}$ & $53.7 \%$ & $38.5 \%$ & $45.8 \%$ & $43.3 \%$ & $47.2 \%$ & $44.3 \%$ & $46.7 \%$ & $44.9 \%$ \\
\hline
\end{tabular}

Note: Loading lower than .35 are not presented.

Source: Autor's elaboration

\section{Study 2: confirmatory factor analysis}

\section{Participants}

This study consists of 4 samples corresponding to the four groups of products: banks, dairy products, fashion, and cellular providers. In the banks sample 239 customers participated, 54\% of which were female, mean age $41.6(S D=14.6) .243$ customers participated in the dairy products sample, $48 \%$ of which were female, mean age $42.8(S D=15.7)$. 214 customers participated in the fashion sample, $49 \%$ of which were female, mean age $40.9(S D=14.1) .230$ customers participated in the cellular products sample, $50 \%$ of which were female, mean age 42.3 ( $S D=$ 16.3). All participants were asked to answer the Lovemarks questionnaire with regard to the products of interest. The data for this study was collected from an Internet panel.

\section{Results}

Results are presented in three sections. In the first section, descriptive statistics and Cronbach's alphas are presented for the two Lovemarks subscales: respect and love along with Pearson correlations between the two 
sub-scales. In the second section, confirmatory factor analyses are presented for each of the four groups of products. In the third section, the equivalence Avichai Shuv-Ami
A new scale of brand of the factor structure across the four groups of products is presented.

Table 1 presents descriptive statistics and an indicated intercorrelation for the respect and love subscales. As shown, internal reliability as assessed by Cronbach's alpha was high and exceeded .90 for both the respect and love sub-scales in each of the four groups of products. In addition, as expected, love and respect were significantly and positively correlated in all four groups of products and ranged between .76 and .82. These high correlations may indicate that the two subscales represent a higher order construct, namely Lovemarks.

Tab. 2: Descriptive statistics, Cronbach's alpha and inter-correlations for the Lovemarks scale

\begin{tabular}{|lccccccc|}
\hline & \multicolumn{3}{c}{ Respect } & \multicolumn{5}{c|}{ Love } \\
\cline { 2 - 7 } & $M$ & $S D$ & $\alpha$ & $M$ & $S D$ & $\alpha$ & $r$ \\
\cline { 2 - 7 } Banks & 6.43 & 2.45 & .98 & 5.47 & 2.75 & .96 & $.78^{* * *}$ \\
Dairy products & 6.25 & 2.41 & .94 & 5.60 & 2.53 & .90 & $.76^{* * *}$ \\
Fashion & 5.91 & 2.59 & .96 & 5.65 & 2.67 & .93 & $.82^{* * *}$ \\
Cellular providers & 6.27 & 2.87 & .96 & 5.12 & 3.05 & .93 & $.77^{* * *}$ \\
\hline
\end{tabular}

Note. ${ }^{* *} \mathrm{p}<.001$

Source: Autor's elaboration

In order to validate the hypothesized one-second order factor model, four Confirmatory Factor Analysis (CFA) were examined, one for each group of products. In addition, two-nested models - a first-order factor model and a two-correlated first-order factor model - were also tested for comparison purposes. CFA was analyzed with AMOS 18.0 structural equation modeling (Arbuckle, 2009) using the maximum-likelihood estimation method. The models' fit was assessed using the following goodness-of-fit indices (see $\mathrm{Hu}$ and Bentler; 1999): Chi-square (Tabachnik and Fidell, 2007), Standardized Root-Mean-Square Error of Approximation (RMSEA; Kline, 1998), Normed Fit Index (NFI; Bentler and Bonett, 1980), Tucker-Lewis Index (TLI; Bentler and Bonett, 1980), Comparative Fit Index (CFI; Rigdon, 1996), and Akaike Information Criterion (AIC; Tabachnik and Fidell, 2007). A NFI, CFI, and TLI close to or greater than .95 and a RMSEA equal to or less than .08 are indicative of an acceptable fit (Hu and Bentler; 1999; Tabachnik and Fidell, 2007). Model comparisons were based on the Chi-square per $d f$ difference and on differences between the models fit indices.

CFA results for the hypothesized model and the additional two comparison models are presented in table 2. As can be seen in the table, the one first-order factor model had unacceptable fit indices for all four groups, suggesting that the most restricted model is inappropriate for explaining the scale's inter-items covariation. The hypothesized one secondorder factor model and the two correlated first-order factor models showed acceptable fit to the data. Although the one second-order factor model and the two correlated first-order factor model showed similar fit indices, the 
sinergie

italian journal of management Vol. 35, N. 102, 2017 high loadings of the two first-order factors in the second-order factor may suggest that the hypothesized one second-order factor model is preferred.

Tab. 3: Fit indices for alternative measurement models of the Lovemarks scale

\begin{tabular}{|l|c|c|c|c|c|c|c|}
\hline Models & $\chi^{2}$ & df & RMSEA & NFI & TLI & CFI & AIC \\
\hline Banks & & & & & & & \\
\hline One first-order factor model & $438.76^{* * *}$ & 9 & .43 & .79 & .52 & .79 & 474.76 \\
\hline Two correlated first-order factor model & $34.51^{* * *}$ & 8 & .08 & .98 & .97 & .99 & 72.51 \\
\hline One second-order factor model (Hypothesized) & $34.51^{* * *}$ & 8 & .08 & .98 & .97 & .99 & 72.51 \\
\hline Dairy products & & & & & & & \\
\hline One first-order factor model & $173.02^{* * *}$ & 9 & .27 & .87 & .72 & .88 & 209.02 \\
\hline Two correlated first-order factor model & $37.03^{* * *}$ & 8 & .07 & .97 & .94 & .98 & 75.03 \\
\hline One second-order factor model (Hypothesized) & $37.03^{* * *}$ & 8 & .07 & .97 & .94 & .98 & 75.03 \\
\hline Fashion & & & & & & & \\
\hline One first-order factor model & $265.95^{* * *}$ & 9 & 34 & .84 & .64 & .85 & 301.95 \\
\hline Two correlated first-order factor model & $25.39^{* *}$ & 8 & .06 & .98 & .97 & .99 & 63.39 \\
\hline One second-order factor model (Hypothesized) $^{\mathrm{a}}$ & $25.39^{* *}$ & 8 & .06 & .98 & .97 & .99 & 63.39 \\
\hline Cellular providers & & & & & & & \\
\hline One first-order factor model $^{\mathrm{a}}$ & $312.02^{* * *}$ & 9 & .36 & .82 & .58 & .82 & 348.02 \\
\hline Two correlated first-order factor model & $59.21^{* * *}$ & 8 & .09 & .97 & .92 & .97 & 97.21 \\
\hline One second-order factor model (Hypothesized) $^{\mathrm{a}}$ & $59.21^{* * *}$ & 8 & .09 & .97 & .92 & .97 & 97.21 \\
\hline
\end{tabular}

Note. ${ }^{* * *} \mathrm{p}<.001$

RMSEA $=$ Root Mean Square Error of Approximation, NFI $=$ Normed Fit Index, TLI $=$ Tucker-Lewis Index, CFI = Comparative Fit Index, AIC = Akaike Information Criterion, $\Delta \chi^{2}(\mathrm{df})$ represent the difference in comparison to the hypothesized model. a. For identification purposes, the loading of the first item in each first-order factor was set to 1 , and the disturbances of the two first-order factors were constrained to be equal.

Source: Autor's elaboration

The one second-order factor model standardized coefficients are presented in Figure 4. All items loadings on respective first-order factors were greater than .79 , suggesting good convergence. Second order loading exceeded .87, suggesting that higher order factors explain more than the recommended half of the variance in lower order factors. Overall, evidence of convergent validity was gained and the hypothesized model can, thus, be considered a plausible and sufficient measurement for the Lovemarks scale.

To test the equivalence of the strength of the relations among variables in the structural model in the four groups of products, the path coefficients (i.e. loadings) were constrained to equality and this model was compared to the model in which path coefficients were free. For these invariance analyses, Little suggested (1997) that a none significant chi-square difference and TLI, NFI, CFI, and RMSEA differences that do not exceed .05 indicate paths equivalence. Using the multi-group analysis in AMOS, I assessed the fit indices of the free model, a model with no constrained paths. Results indicated an acceptable fit to the data, chi-square (35) = $161.80, p<.001, N F I=.98, T L I=.95, C F I=.98, R M S E A=.06$. Next, I examined the equivalence of the paths across products by constraining all 
path coefficients. The model that was constrained to equality also showed acceptable fit to the data, chi-square $(47)=176.33, p<.001, N F I=.97$, TLI Avichai Shuv-Ami $=.97, C F I=.98, R M S E A=.05$. Comparing the fit of the constrained model to the fit of a baseline model in which none of the measurement coefficients were constrained yielded a non-significant chi-square difference $\left(\Delta \chi^{2}=\right.$ $14.53, \Delta d f=12, N S$, and a change in fit indices that is lower than $.05(\triangle N F I$ $=.01, \triangle T L I=.02, \triangle C F I=.0$, and $\triangle R M S E A=.01$ ). These results suggest that the strength of the first-order loadings and that of the second-order loadings were equivalent across the four groups of products. Figure 3 presents the standardized constrained coefficients.

Fig. 4: Second order factor analysis of the Brand Lovemarks Scale

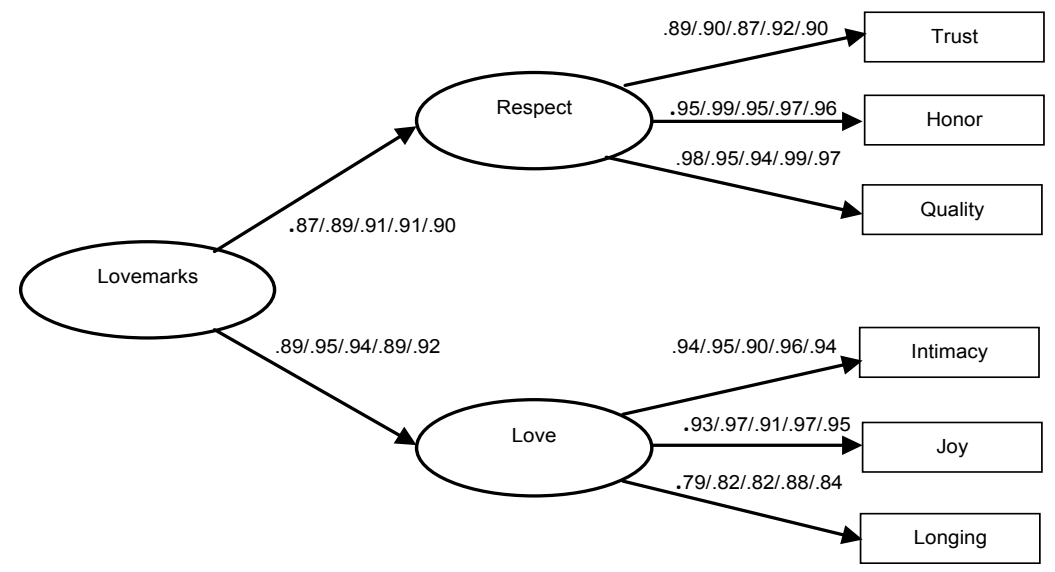

Note. Values represent standardized path coefficients for cellular providers, fashion, dairy products, and banks respectively. Bold values represent the standardized constrained coefficients.

Source: Autor's elaboration

\section{Study 3: nomological validity}

\section{Participants}

This study consists of 4 samples corresponding to the four groups of products: banks, dairy products, fashion, and cellular providers. In the banks sample 203 customers participated, $47 \%$ of which were female, mean age 42.1 $(S D=14.8)$. In the dairy products sample 212 customers participated, $51 \%$ of which were female, mean age $41.3(S D=15.2)$. In the fashion sample 206 customers participated, $49 \%$ of which were female, mean age 43.6 (SD $=14.6)$. In the cellular products sample 208 customers participated, $51 \%$ of which were female, mean age $41.9(S D=15.1)$. All participants were asked to answer the questionnaire with regard to the products of interest. The data for this study was collected from an Internet panel. 


\section{Instruments}

Using the Lovemarks scale, the items were the same as in studies 1 and 2. The internal reliabilities for the respect sub-scales were high: for banks $\alpha=.97$, for dairy products $\alpha=.96$, for fashion $\alpha=.96$, and for cellular products $\alpha=.96$. Internal reliabilities for the love sub-scales were high: for banks $\alpha=.90$, for dairy products $\alpha=.91$, for fashion $\alpha=.93$, and for cellular providers $\alpha=.92$. Internal reliabilities for the overall Lovemarks scale were high: for banks $\alpha=.95$, for dairy products $\alpha=.95$, for fashion $\alpha$ $=.96$, and for cellular providers $\alpha=.96$.

\section{Results}

The nomological validity of the Lovemarks scale was assessed by testing its relations with four relevant scales in its hypothesized nomological network in all four samples. Table 4 presents the correlations between the research variables. As expected, results indicate significant and strong correlations of the Lovemarks sub-scales and overall scores with overall attitudes, recommendations, preferences, and price premiums. Thus these correlations provide evidence for the nomological validity of the Lovemarks scale.

Tab. 4: Correlations among the research variables

\begin{tabular}{|c|c|c|c|}
\hline & \multicolumn{3}{|l|}{ Lovemarks } \\
\hline & Respect & Love & Overall score \\
\hline \multicolumn{4}{|l|}{ Banks } \\
\hline Overall attitude & $.70^{\star * *}$ & $.64^{* * *}$ & $.69^{* * *}$ \\
\hline Recommendation & $.69^{* * *}$ & $.66^{* * *}$ & $.70^{* \star *}$ \\
\hline Preference & $.62^{\star * *}$ & $.58^{\star * *}$ & $.62^{* * *}$ \\
\hline Price premium & $.54^{* * *}$ & $.76^{* * *}$ & $.69^{* * *}$ \\
\hline \multicolumn{4}{|l|}{ Dairy products } \\
\hline Overall attitude & $.62^{\star * *}$ & $.59^{\star * *}$ & $.64^{* * *}$ \\
\hline Recommendation & $.59^{\star * *}$ & $.59^{* * *}$ & $.63^{* * *}$ \\
\hline Preference & $.54^{\star \star \star}$ & $.52^{* * *}$ & $.54^{\star \star \star}$ \\
\hline Price premium & $.49^{* * *}$ & $.66^{* * *}$ & $.62^{\star \star \star}$ \\
\hline \multicolumn{4}{|l|}{ Fashion } \\
\hline Overall attitude & $.69^{* * *}$ & $.69^{* * *}$ & $.74^{* * *}$ \\
\hline Recommendation & $.69^{* * *}$ & $.70^{\star * *}$ & $.74^{* * *}$ \\
\hline Preference & $.62^{* * *}$ & $.61^{* * *}$ & $.66^{* * *}$ \\
\hline Price premium & $.47^{\star * *}$ & $.72^{\star * *}$ & $.64^{* * *}$ \\
\hline \multicolumn{4}{|l|}{ Cellular providers } \\
\hline Overall attitude & $.55^{\star * *}$ & $.56^{* * *}$ & $.58^{\star * \star}$ \\
\hline Recommendation & $.55^{\star * *}$ & $.48^{\star * *}$ & $.54^{* * *}$ \\
\hline Preference & $.47^{\star * *}$ & $.45^{* * *}$ & $.46^{* * *}$ \\
\hline Price premium & $.51^{\star * *}$ & $.65^{* * *}$ & $.62^{* * *}$ \\
\hline
\end{tabular}

Note. ${ }^{* *} \mathrm{p}<.001$

Source: Autor's elaboration 


\section{Conclusions and discussions}

This study developed a new Lovemarks scale for consumer behavior. Lovemarks is a market position in the mind of consumers that represents both high love and high respect for a brand. It is the place for a desired brand and a place where all brands want to be (Kevin, 2004). The reliability and validity of the scale were established in relation to four different product categories. As hypothesized, the EFA showed that a two-factor solution was the preferred measurement model. Also as hypothesized, the CFA showed that the two oblique first-order factors - love and respect - suffice to account for covariations of the brand. The Lovemarks brand scale items and the second-order factors that represent the overall Brand Lovemarks underlie the first-order factors.

Recently, Cho et al. (2015) suggested a "Brand Lovmarks" scale using Roberts' (2004) dimensions of love and respect. The findings of Cho et al. (2015) supported Roberts' theory that Lovemarks have a strong influence on brand loyalty. However, contrary to this theory, they also found that mystery and sensuality are more related to respect then to love. The new scale of Lovemarks suggested here measures love based on well-established marketing literature and suggests that love is reflected by intimacy, longing love (e.g., Ahuvia, 2005; Carroll and Ahuvia, 2006; Sarkar, 2011; Whang et al., 2004) and joy (Albert et al., 2008; Carroll and Ahuvia, 2006). In other words, the love of a brand is not just romantic and therefore animated by intimacy and passion (Sternberg, 1986). Similar to Rossiter (2012), the present study also argues that brand love should not be measured by its related consequences (e.g., "commitment", "very attached", "satisfaction", and "compares well with ideal product", "meets needs perfectly" and "makes life worth living"), as recently suggested by Batra et al. (2012). On the contrary, this study does not support Rossiter's (2012) criticism of Batra et al. (2012) and the long stream of research that sustains that brand love is discrete and categorical. In fact Rossiter (2012) suggested a new type of continuous and single item scale that measures "Brand Love-Hate" (a 5-level scale of "hate dislike - neutral - like - love") and not "Brand Love".

Brand Lovemarks are not just about love. They are also about respect, which represents the functional aspects of the brand - the quality, trust and honor of the brand. The current study offers new definitions for brand love, brand respect and brand Lovemarks. This study demonstrates that brand Lovemarks have strong and positive correlations with overall attitude towards the brand, brand preference, price premium and brand recommendation. These strong correlations suggest that the brand Lovemarks construct is an important driver for brand relationship. In contrast to Batra et al. (2012), emotional love is a decisive factor in developing a prolonged - rather than short term or episodic - relationship with a specific brand.

This scale helps to predict consumer behavior and set an effective marketing strategy for the brand. The scale further provides the ability to evaluate the factional and main emotional strength and weakness of the brand; it thus gives directions for product adjustments and establishes effective advertising and marketing communication strategies. The "Lovemarks" scale suggested here can help marketing managers in the 
sinergie Vol. 35, N. 102, 2017

process of building desired brands in terms of which emphasis is needed for the brand's attributes and communication messages and should it be more emotional (Love) or functional (Respect). The fact that the willingness to pay more (price premium) is strongly associated with the Lovemarks scale may also provide direction for brand pricing strategy. The measured scoring strength on the brand Lovemarks scale may suggest the price level that consumers would be willing to pay for that brand.

The main limitation of the current study is that Study 2 used CFA testing only for second-order factors and not third-order factors, which would have enabled the antecedents of the scale's items (such as intimacy or trust etc.) to be tested. Future research may test the current scale antecedents and focus on testing the relationship of this Brand Lovemarks scale with brand commitment, brand loyalty and satisfaction with the brand's performance brand image and overall brand personality. It can thus depict the detailed process of purchasing behavior. Such a measurement may even be used for countries as brands and tourist attractions. Moreover, such Lovemarks measurements may be applied to the avid enthusiasm of sports fans for their favorite teams as they rise or fall, or win or lose, during a season.

\section{References}

AAKER D.A. (1996), Measuring Brand Equity across products and markets", California Management Review, vol. 38, n. 3, pp. 102-20.

AHUVIA A.C. (2005), "Beyond the extended self: Loved objects and consumers' identity narratives", Journal of Consumer Research, vol. 32, n. 1, pp. 171-184.

ARBUCKLE J.L. (2009), Amos 18 User's Guide, SPSS Incorporated.

BATRA R., AHUVIA A.C., BAGOZZI R.P. (2012), "Brand love", Journal of Marketing, vol. 76, n. 2, pp. 1-16.

BENTLER P.M., BONETT D.G. (1980), "Significance Tests and Goodness of Fit in the Analysis of Covariance Structures", Psychological Bulletin, vol. 88, n. 3, pp. 588-606.

BERGKVIST L. BECH-LARSEN T. (2010), "Two studies of consequences and actionable antecedents of brand love", Brand Management, vol. 17, n. 7, pp. 504-518.

BROADBENT S., BRIDSON K., FERKINS L., and RENTSCHLER R. (2010), "Brand love, Brand image and Loyalty in Australian Elite Sport", Proceedings, Australian and New Zealand Marketing Academy Conference, ANZMAC,Christchurch, New Zealand.

CARROL B.A., AHUVIA A.C. (2006), "Some antecedents and outcomes of brand love", Marketing Letters, vol. 17, n. 2, pp. 79-89.

CHAUDHURI A. HOLBROOK B.M. (2001), "The Chain of Effects from Brand Trust and Brand Affect to Brand Performance: The Role of Brand Loyalty", Journal of Marketing, vol. 65, 2 April, pp. 81-93.

CHO E., FIORE A.M. RUSSELL W.D (2015), "Validation of a Fashion Brand Image Scale Capturing Cognitive, Sensory, and Affective Associations: Testing Its Role in an Extended Brand Equity Model", Psychology and Marketing, vol. 32, n. 1, pp. 28-48.

HAIR J.F., BLACK C.W., BABIN J.B., ANDERSON E.R., TATHAM L.R. (2006), Multivariate Data Analysis, (6 $6^{\text {th }}$ ed.),Upper Saddle River, NJ: Pearson Prentice Hall. 
HELSON H. (1964), Adaptation-Level Theory, Harper \& Row, New York.

HOWARD J.A., SHETH, J.N. (1969), The Theory of Buyer Behavior, John Wiley \& Sons, New York.

HU L.T., BENTLER M.P. (1999), "Cutoff Criteria for Fit Indexes in Covariance Structure Analysis: Conventional Criteria Versus New Alternatives", Structural Equation Modeling, vol. 6, n. 1, pp. 1-55.

JARVIS B.C., MACKENZIE B.S., PODSAKOFF M.P. (2003), "A Critical Review of Construct Indicators and Measurement Model Misspecification in Marketing and Consumer Research", Journal of Consumer Research, vol. 30, n. 9, pp. 199-218.

KELLER L.K. (1993), "Conceptualizing, measuring, and managing customer-based brand equity", Journal of Marketing, vol. 57, n. 1, pp. 1-22.

KELLER L.K. (2008), Strategic Brand Management, Third Edition, Prentice Hall, Englewood Cliffs, New Jersey.

KELLER L.K., and Donald R. Lehmann, (2006), "Brands and Branding: Research Findings and Future Priorities", Marketing Science, vol. 25, n. 6, NovemberDecember, pp. 740-759.

KLINE R.B. (1998), "Software review: Software programs for structural equation modeling: Amos, EQS, and LISREL”, Journal of Psychoeducational Assessment, vol. 16, n. 4, pp. 343-364.

LITTLE D.T. (1997), "Mean and Covariance Structures (MACS), Analyses of CrossCultural Data: Practical and Theoretical Issues", Multivariate Behavioral Research, vol. 32, n. 1, pp. 53-76.

MANO H., OLIVER L.R. (1993), "Assessing the Dimensionality and Structure of the Consumption Experience: Evaluation, Feeling, and Satisfaction", Journal of Consumer Research, vol. 20, n. 3, pp. 451-466.

MAXIAN W., BRADLEY D.S., WISE W., TOULOUSE N.E. (2013), "Brand Love is in the Heart: Physiological Responding to Advertised Brands", Psychology and Marketing, vol. 30, n. 6, pp. 469-478.

NOEL A., MERUNKA D., VALWTTE-FLORENCE P. (2008), "When consumers love their brands: Exploring the concept and its dimensions", Journal of Business Research, vol. 61, pp. 1062-1075.

OLIVER L.R. (1980), "A Cognitive Model of the Antecedents and Consequences of Satisfaction Decisions", Journal of Marketing Research, vol. 17, n. 4, pp. 460469.

OLIVER L.R. (1996), Satisfaction: A Behavioral Perspective on the Consumer, McGraw-Hill, New York.

OLIVER L.R. (1993), "Cognitive, Affective, and Attribute Bases of the Satisfaction Response”, Journal of Consumer Research, vol. 20, n. 3, pp. 418-430.

ORTIZ H.M., HARRISON M.P. (2011), "Crazy Little Thing Called Love: A Consumer-Retailer Relationship", Journal of Marketing Development and Competitiveness, vol. 5, n. 3, pp. 68-80.

PATWARDHAN H., BALASUBRAMANIAN K.S. (2013), "Reflections on emotional attachment to brands: Brand romance and brand love", Journal of Customer Behaviour, vol. 12, n. 1, pp. 73-79.

PAVEL C. (2013), "What is Behind the Lovemarks Concept?", Quality - Access to Success., vol. 14, n. 2 (May Supplement 2), pp. 482-489.

PAWLE P., COOPER P. (2006), "Measuring Emotion - Lovemarks, The Future Beyond Brands", Journal of Advertising Research, vol. 46, n. 1, pp. 38-48. 


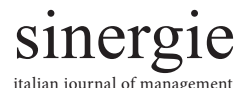

Vol. 35, N. 102, 2017

RIGDON E.E. (1996), "CFI versus RMSEA: A Comparison of Two Fit Indexes for Structural Equation Modeling", Structural Equation Modeling: A Multidisciplinary Journal, vol. 3, n. 4, pp. 369-379.

ROBERTS K. (2004), Lovemarks: The Future Beyond Brands, Powerhouse Books, NY.

ROBERTS K. (2005), Lovemarks: The Future Beyond Brands, (2nd edition), Powerhouse Books, NY.

ROSSITIER R.J, BELLMAN S. (2012), “Emotional Branding Pays off: How Brands Meet Share of Requirements Through Bonding, Companionship, and Love", Journal of Advertising Research, vol. 52, n. 3, pp. 291-296.

ROSSITIER R.J (2012), "A new C-OAR-SE-based content-valid and predictively valid measure that distinguishes brand love from brand liking", Marketing Letters, vol. 23, n. 3, pp. 905-916.

RUBIN Z. (1970), "Measurement of Romantic Love", Journal of Personality and Social Psychology, vol. 16, n. 2, pp. 265-273.

SARKAR A. (2011), "Romancing with A Brand: A Conceptual Analysis of Romanic Consumer- Brand Relationship", Management and Marketing Challenges for the Knowledge Society, vol. 6, n. 1, pp. 79-94.

SHIMP A.T., MADDEN J.T. (1988), “Consumer-Object Relations: A Conceptual Framework Based Analogously on Sternberg's Triangular Theory of Love", Advances in Consumer Research, vol. 15, n. 1, pp. pp. 163-168.

SHUV-AMI A. (2011), "The Impact of Love and Quality on Brand Satisfaction and Intentions", presented and published in the Proceedings of the ANZMAC Conference, Perth Australia, November.

SHUV-AMI A. (2012), "Brand Commitment: A New Four-Dimensional (4 E’s), Conceptualization and Scale", Journal of Customer Behaviour, Forthcoming autumn issue, vol. 11, n. 3, pp. 281-305.

SHUV-AMI A. (2012), "Brand Commitment: A New Four-Dimensional (4 E’s), Conceptualization and Scale", Journal of Customer Behaviour, vol. 11, n. 3, pp. 281-305.

STERNBERG R.J. (1986), “A triangular theory of love”, Psychological Review, vol. 93, n. 2, pp. 119-135.

TABACHNICK G.B., FIDELL S.L. (2007), Experimental designs using ANOVA, Thomson/Brooks/Cole.

TSIOTSON R. (2006), "The Role of Perceived Product Quality and Overall Satisfaction on Purchase Intentions", International Journal of Consumer Studies, vol. 2, March, pp. 207-217.

WEAVER D., BRICKMAN P. (1974), "Expectancy, Feedback and Disconfirmation as Independent Factors in Outcome Satisfaction", Journal of Personality and Social Psychology, vol. 30, n. 3, pp. 420-428.

WHANG Y.O., ALLEN J., SAHOURY N., ZHANG H. (2004), "Falling in Love with

sinergie a Product: The Structure of a Romantic Consumer-Product Relationship", Advances in Consumer Research, vol. 31, n. 1, pp. 320-327.

ISSN 0393-5108 DOI $10.7433 / \mathrm{s} 102.2017 .07$ pp. 85-102

\section{Academic or professional position and contacts}

Avichai Shuv-Ami

Professor of Marketing

The School of Business Administration, Peres Academic Center

e-mail: shuvami@gmail.com,shuvami@pac.ac.il 